\title{
Article \\ Oral Mesenchymal Stromal Cells in Systemic Sclerosis: Characterization and Response to a Hyaluronic-Acid-Based Biomaterial
}

\author{
Alina Stanomir ${ }^{1}$ (D), Carmen Mihaela Mihu ${ }^{2}$, Simona Rednic ${ }^{3}$, Cristina Pamfil ${ }^{3}$, Alexandra Roman 1,*iD, \\ Andrada Soancă ${ }^{1}$, Iulia Cristina Micu ${ }^{1}$, Adriana Elena Bulboacă ${ }^{4}$, Ștefan Ioan Stratul ${ }^{5}$, Aurel Popa-Wagner ${ }^{6,7}(\mathbb{D}$ \\ and Emoke Pall ${ }^{8}$ (D)
}

\section{check for}

updates

Citation: Stanomir, A.; Mihu, C.M. Rednic, S.; Pamfil, C.; Roman, A.; Soancă, A.; Micu, I.C.; Bulboacă, A.E.; Stratul, S.I.; Popa-Wagner, A.; et al. Oral Mesenchymal Stromal Cells in Systemic Sclerosis: Characterization and Response to a Hyaluronic-AcidBased Biomaterial. Appl. Sci. 2021, 11 8101. https://doi.org/10.3390/ app11178101

Academic Editor: Luca Testarelli

Received: 15 July 2021

Accepted: 27 August 2021

Published: 31 August 2021

Publisher's Note: MDPI stays neutral with regard to jurisdictional claims in published maps and institutional affiliations.

Copyright: (c) 2021 by the authors. Licensee MDPI, Basel, Switzerland. This article is an open access article distributed under the terms and conditions of the Creative Commons Attribution (CC BY) license (https:/ / creativecommons.org/licenses/by/ $4.0 /)$.
1 Department of Periodontology, Faculty of Dental Medicine, Iuliu Haţieganu University of Medicine and Pharmacy Cluj-Napoca, Victor Babeş St., No. 15, 400012 Cluj-Napoca, Romania; alina.stanomir@yahoo.com (A.S.); andrapopovici@gmail.com (A.S.); i.cristina.micu@gmail.com (I.C.M.)

2 Discipline of Histology, Department of Morphological Sciences, Iuliu Haţieganu University of Medicine and Pharmacy Cluj-Napoca, Louis Pasteur St., No. 6, 400349 Cluj-Napoca, Romania; carmenmihu2004@yahoo.com

3 Discipline of Rheumatology, Iuliu Haţieganu University of Medicine and Pharmacy Cluj-Napoca, Clinicilor St., No. 2, 400000 Cluj-Napoca, Romania; srednic.umfcluj@gmail.com (S.R.); cristinapamfil.umfcluj@gmail.com (C.P.)

4 Department of Pathophysiology, Iuliu Haţieganu University of Medicine and Pharmacy Cluj-Napoca, Victor Babes St., No. 2-4, 400012 Cluj-Napoca, Romania; adriana.bulboaca@umfcluj.ro

5 Department of Periodontology, Anton Sculean Center for Research of Periodontal and Periimplant Diseases, Faculty of Dental Medicine, Victor Babes University of Medicine and Pharmacy, Bulevardul Revolutiei din 1989, No. 9, 300230 Timisoara, Romania; sbs@online.ro

6 Research Center for Normal and Pathological Aging, ARES, University of Medicine and Pharmacy of Craiova, Petru Rares Str., No. 2-4, 200349 Craiova, Romania; aurel.popa2011@gmail.com

7 Chair of Vascular Neurology and Dementia, University of Medicine, Essen, Hufeland Str., No. 55, 45122 Essen, Germany

8 Department of Veterinary Reproduction, Obstetrics and Gynaecology, Faculty of Veterinary Medicine, University of Agricultural Sciences and Veterinary Medicine, Mănăștur St., No. 3-5, 400372 Cluj-Napoca, Romania; pallemoke@gmail.com

* Correspondence: veve_alexandra@yahoo.com; Tel.: +40-264-597256

Abstract: Introduction. As oral mesenchymal stromal cells (MSCs) have not, to date, been isolated from systemic sclerosis (SSc) patients, the aim of this in vitro experiment was to characterize gingival MSCs (SScgMSCs) and granulation tissue MSCs (SScgtMSCs) from SSc and to evaluate their functionality in comparison to healthy MSCs (hMSCs), in normal or hyaluronic acid (HA) culture media. Materials and Methods. Isolated cells were described by immunophenotyping of surface antigen make-up and by trilineage mesenchymal differentiation capacity. Colony-Forming UnitFibroblast (CFU-F) test and migration potential evaluated MSC functionality. Results. All types of MSCs displayed positivity for the following surface markers: CD29, CD73, CD90, CD105, CD44, and CD79a. These cells did not express CD34, CD45, HL-DR, and CD14. Isolated MSCs differentiated into osteoblasts, adipocytes, and chondroblasts. The frequency of CFU-F for SScgtMSCs was significantly lower than that of hMSCs $(p=0.05)$ and SScgMSCs $(p=0.004)$ in normal medium, and also markedly lower than that of SScgMSCs $(p=0.09)$ in HA medium. Following HA exposure, both SScgMSCs and SScgtMSCs migrated significantly less ( $p=0.033$ and $p=0.005$, respectively) than hMSCs. Conclusions. A reduced functionality of MSCs derived from SSc as compared to hMSCs was observed. HA in culture medium appeared to significantly stimulate the migration potential of hMSCs.

Keywords: mesenchymal stromal cell; surface antigens; differentiation; systemic sclerosis; hyaluronic acid 


\section{Introduction}

Systemic sclerosis (SSc) is a complex multisystem disease of autoimmune origin defined by excessive collagen deposits by pathologic fibroblasts [1] and consecutive fibrosis of the skin and internal organs and by hyper-reactivity and obliteration of the microvasculature [2], which induce general and oral handicaps [3]. SSc has been associated with impaired oral health, including periodontal problems. SSc patients have increased periodontal indicators (deep periodontal pockets, plaque deposits, and bleeding on probing) when compared to controls [4-6]. SSc patients can also be at increased risk to develop periodontal pathologies due to xerostomia and impaired oral hygiene consecutive to reduced manual dexterity and mouth opening, the use of immunosuppressive drugs [7], as well as periodontal morphopathological changes associated with the systemic disease $[8,9]$.

Mesenchymal stromal cells (MSCs) are important players participating in the complex network of exchange involved in tissue and organ regeneration and homeostasis [10]. Bone marrow MSCs from SSc were shown to display differentiation impairments, a loss in angiogenic potential based on the diminished capability to induce endothelial precursors [11], increased expression of senescent markers [11,12], and a modified microRNAs (miRs) expression profile relevant for cell abnormalities [12], while maintaining immunosuppressive and immune-regulatory functions [11]. Other studies reported more consistent functional properties of bone marrow MSCs from SSc in comparison to MSCs from healthy patients $[13,14]$.

Due to potential yet insufficiently validated abnormalities of oral MSCs in SSc patients that may hamper periodontal regeneration, the use of biomaterials with a stimulating effect on local progenitors as adjuvant of periodontal therapies appears to be of particular interest. To our knowledge, oral MSCs have not been isolated and characterized from SSc, nor has their functionality been evaluated. Moreover, no reports are available concerning their behavior in relation to biomaterials used in periodontal practice.

Hyaluronan is a natural low-molecular-weight glycosaminoglycan identified in different fluids of the organism and an essential ingredient of the extracellular matrix of mineralized and non-mineralized tissues such as periodontal components [15]. Hyaluronan is more abundant in the gingiva and in the periodontal ligament than in the alveolar bone and cementum [16]. The term hyaluronan is used to refer to both forms of this molecule (acid-hyaluronic acid HA or salt—sodium or potassium hyaluronate) [16]. It is also important to acknowledge that hyaluronan has bacteriostatic and fungistatic effects $[17,18]$, as well as anti-inflammatory, anti-oedematous [19], osteoinductive [20,21], pro-angiogenetic [22], and wound-healing-promoting properties [23]. Although no firm recommendations on hyaluronan periodontal clinical indications have been developed, the product was used in periodontology as an adjunctive product to nonsurgical and /or surgical therapies to diminish inflammation and induce healing [16,24]. Based on the above-mentioned properties, HA could be used as an adjunctive biomaterial to stimulate repair and regeneration after periodontal procedures. Complex treatments based on HA associated with adipose tissue-derived MSCs have already been provided to aid the management of complex lesions in SSc patients [14]. Although more clinical studies reporting on the clinical benefices of HA need to be conducted, it is essential to first improve information on the effect of this molecule on the behavior of oral progenitor cells implicated in periodontal healing after periodontal therapies. Further studies are required to isolate and gain insights into the capacities of oral MSCs to sustain periodontal regeneration in SSc.

Against this backdrop, the aim of this in vitro study was to provide the first comprehensive characterization of two oral lines of MSCs isolated from SSc and to assess their functionality in comparison to MSCs from a healthy patient. In addition, our study aims to observe the behavior of both SSc- and healthy MSCs in contact with an HA-based commercial dental product. For the purpose of this study, the following null hypothesis was tested: the behavior of SSc-MSCs does not differ from that of healthy MSCs. 


\section{Materials and Methods}

\subsection{Study Design}

The experiments were developed based on a protocol authorized by the Ethical Board of the Iuliu Haţieganu University (No. 96/9.03.2020). Before oral tissue harvesting, patients were informed of the research protocol and details, and they were asked to give a signed informed consent. The investigations carried out in the present study meet the regulations contained in the Declaration of Helsinki on experiments on human subjects and were planned and performed in accordance with EU and national legal frameworks.

Putative mesenchymal stem cells isolated from the non-inflamed gingiva (SScgMSCs) and granulation tissue from an apical lesion (SScgtMSCs) of a systemic sclerosis patient were grown and fully described by immunophenotyping of external antigen make-up and by trilineage mesenchymal differentiation potential following the standard minimal criteria recommended by the International Society for Cellular Therapy [25]. The influence of HA on differentiation abilities of isolated cells has also been investigated by adding a commercial HA-based biomaterial into differentiation media.

Functionality tests (Colony-Forming Unit-Fibroblast/CFU-F and migratory potential) were performed to comparatively observe the properties of MSC lineages as well as the influence of the HA-based biomaterial on MSCs. For observing the influence of the biomaterial on MSCs, experimental culture media were prepared by supplementing the standard culture medium with the biomaterial applied on the culture recipient ( $\mathrm{Nunc}^{\mathrm{TM}}$, Thermo Fisher Scientific, Waltham, MA, USA).

All comparisons were made to a gingival cell line isolated from a healthy patient and previously reported [26] and named healthy MSCs (hMSCs). The investigations were realized in triplicate.

\subsection{Mesenchymal Stem Cell (MSCs) Isolation and Characterization \\ 2.2.1. Isolation of MSCs}

The SScgMSCs and SScgtMSCs were isolated from the gingiva and an apical lesion, collected after the extraction of a molar from a 42-year-old patient diagnosed with systemic sclerosis based on current diagnosis criteria. The patient was diagnosed in 2017 with limited systemic sclerosis characterized by anticentromere antibody positivity and Raynaud's phenomenon, as well as joint, skin (Rodnan skin score of 8, facial and palmar telangiectasia, and digital pitting without overt digital ulcerations), and gastrointestinal involvement (esophageal dysmotility, gastroesophageal reflux disease). The patient received Methotrexate $10 \mathrm{mg}$ /week and symptomatic treatment (vasodilators, proton pump inhibitors, etc.).

The hMSCs were obtained from gingival tissues harvested from a 34-year-old female smoker, in good general health, during mucogingival plastic surgery. Cells were obtained based on the explant culture approach following a protocol given elsewhere [26]. In summary, the tissue pieces were washed with sterile phosphate saline supplemented with $1 \%$ antibiotic-antimycotic (Gibco Life Technologies, Paisley, UK), minced into 1-2 mm fragments, and added to T25 flasks (Thermo Fisher Scientific) pre-treated with fetal bovine serum (FBS) (EuroClone, Pero, MI, Italy) for $20 \mathrm{~min}$. Cells were expanded in propagation medium: Dulbecco's Modified Eagle's Medium/Nutrient F-12 Ham (DMEM/F12; SigmaAldrich, St. Louis, MO, USA) supplemented with 10\% fetal calf serum (Euro Clone), $2 \mathrm{mM}$ glutamine, $1 \%$ non-essential amino acids (NEAA) (Sigma-Aldrich), $1 \mathrm{mM}$ sodium pyruvate (Sigma-Aldrich), and $55 \mathrm{mM} \beta$-mercaptoethanol (Sigma-Aldrich), $1 \%$ antibioticantimycotic $100 \times$ (Sigma-Aldrich). T25 flasks were kept in a humidified atmosphere with $5 \% \mathrm{CO}_{2}$ at $37{ }^{\circ} \mathrm{C}$ and cultured for 5 days. Then, the medium and tissular debris were eliminated. The first passage was made at $50-70 \%$ confluence ( 7 days). The primary culture (passage 0 ) was treated with $0.25 \%$ trypsin and $1 \mathrm{mM}$ EDTA (ethylenediaminetetraacetic acid) (Sigma-Aldrich) for $7 \mathrm{~min}$ at $37^{\circ} \mathrm{C}$ and was passed at a culture expansion ration of 1:4 until passage four. The culture medium was replaced every 3 days [26]. Cells at passage four had been considered for the present experiment. 


\subsubsection{Immunophenotype Characterization of MSCs}

Isolated cells were described through immunophenotype analysis of external antigen make-up and by trilineage mesenchymal differentiation potential. The cells were trypsinized ( $0.25 \%$ trypsin EDTA) (Sigma-Aldrich), washed twice with PBS, and then fixed in $4 \%$ paraformaldehyde (Fluka, Buchs, Switzerland) for $15 \mathrm{~min}$. The cells $\left(1 \times 10^{5} / \mathrm{sample}\right)$ were treated with different fluorochromes conjugated antibodies mAbs (FITC—Fluorescein Isothiocyanate, PE-Phycoerythrin), then incubated with 3\% FBS albumin, washed twice with PBS plus 2\% FBS (EuroClone), and centrifuged for $6 \mathrm{~min}$ at $1800 \mathrm{rpm}$. The cells were resuspended in 300-600 $\mu \mathrm{L}$ of PBS and $2 \%$ FBS (EuroClone). The immunophenotype characterization used some monoclonal antibodies based on the manufacturer's recommendations: CD105 phycoerythrin (PE), CD73 PE, CD90 Fluorescein Isothiocyanate (FITC), CD44 FITC, CD45 FITC, CD34 FITC, CD14 FTIC, CD79 PE, Human Leukocyte Antigen - antigen D Related (HLA-DR) PE (BD Biosciences, San Jose, CA, USA). Negative and positive controls were used. Investigations were performed with a BD FACS Canto II 6-color flow cytometer (BD Bioscience) using BD FACS Diva software (BD Bioscience) version 6.1 .3 [26].

\subsubsection{Trilineage Differentiation Assay and Cytochemical Staining}

A previous protocol of the team was followed to appreciate the differentiation potential of the isolated cells [27]. Cells were trypsinized, counted, and $1 \times 10^{5}$ cells/well were seeded in a 24 -well plate. Then, the cells were cultured to $70 \%$ confluence in standard DMEM/F12 (Sigma-Aldrich) growth medium. The differentiation medium replaced the conventional culture medium. Cells were plated in differentiation media as well as in HA-containing differentiation media.

\subsubsection{Adipocyte Differentiation}

Cells were cultured for 21 days in the adipogenic induction medium. This medium contained: DMEM $4.5 \mathrm{~g} / \mathrm{L}$ glucose (Sigma-Aldrich) supplemented with 10\% FBS (EuroClone), $10^{-6} \mathrm{M}$ dexamethasone (Sigma-Aldrich), $0.5 \mathrm{mM}$ isobutylmethylxanthine (Sigma-Aldrich), $10 \mu \mathrm{g} / \mathrm{mL}$ insulin (Sigma-Aldrich), 1\% L-glutamine, and 1\% antibiotic/antimycotic (SigmaAldrich). The adipogenic medium was refreshed every 3 days. After 21 days, cells were fixed with 10\% formalin (Fluka, Buchs, Switzerland) for $20 \mathrm{~min}$ and washed with $60 \%$ isopropanol (Fluka, Buchs, Switzerland). Then, the cells were stained with Oil Red O (Sigma-Aldrich) for $10 \mathrm{~min}$. The accumulated cytoplasmic lipid droplets were captured with light-field microscopy images ( $\times 10$ magnification, Nikon Eclipse E100 microscope with a DS-2Mv-L2 digital camera, Nikon Instruments, Melville, NY, USA).

\subsubsection{Osteogenic Differentiation}

To appreciate osteogenic differentiation capability, cells were cultured for 10 days in osteogenic induction medium composed by DMEM (Gibco Life Technologies), supplemented with 20\% FBS (EuroClone), $50 \mu \mathrm{M}$ ascorbic acid-2-phosphate (Sigma-Aldrich), $100 \mathrm{nM}$ dexamethasone (Sigma-Aldrich), $10 \mathrm{mM}$ B-glycerophosphate (Sigma-Aldrich), $100 \mathrm{U} / \mathrm{mL}$ penicillin, and $0.1 \mathrm{mg} / \mathrm{mL}$ streptomycin (Sigma-Aldrich). The medium was replaced every 3 days. After 10 days of culture in osteogenic medium, cells were fixed with $4 \%$ paraformaldehyde (Fluka) for $20 \mathrm{~min}$ for immunocytochemical staining and then washed in PBS twice. In order to distinguish the mineralized nodules, $2 \%$ Alizarin Red solution (pH 4.1; Sigma-Aldrich) was added into the culture plates for $10 \mathrm{~min}$ and then washed three times with pure water and air-dried. Light-field microscopy images were taken.

\subsubsection{Chondrogenic Differentiation}

Cells previously aggregated into spheroids were grown for 30 days in chondrogenic induction medium: DMEM/F-12 supplemented with ITS (insulin, transferrin, selenium- Invitrogen, Thermo Fisher Scientific), $10 \mathrm{nM}$ dexamethasone, $50 \mu \mathrm{M}$ ascorbic acid 2-phosphate, $10 \mathrm{ng} / \mathrm{mL}$ of transforming growth factor (TGF-b3) (all reagents from Sigma Aldrich Chemie 
GmbH, Milwaukee, Germany), and 1\% antibiotic/antimycotic (Gibco Life Technologies). The cultures were fixed in $4 \%$ paraformaldehyde and stained with Alcian Blue solution (Sigma-Aldrich) overnight to impart a blue color to the glycosaminoglycans in the chondrocyte's extracellular matrix. After thorough rinsing with pure water, images were captured using light microscopy.

\subsection{Preparation of Experimental Culture Media}

A hyaluronic acid-based commercial gel (hyaDent BG, BioScience, Dummer, Germany) recommended for periodontal applications (crestal augmentations, peri-implantitis, sinus lift, papilla reconstructions, post-extraction sockets) was used for this experiment. Each $\mathrm{ml}$ of the product contains $2 \mathrm{~mL}$ of HA, $16 \mathrm{mg}$ of reticulated HA, $6.9 \mathrm{mg}$ of sodium chloride, and $1 \mathrm{~mL}$ of sterile water. A droplet of the HA product was placed on a well, and after dispersion, the plates were left to dry for $10 \mathrm{~min}$, and then the cell suspension and the propagation medium were added.

\subsection{Generation of Aggregates—Spheroids}

The liquid suspension of cultured MSCs was introduced in a hydrophobic bacterialgrade dish (60 $\mathrm{mm}$ in diameter) (Thermo Scientific Nunc, Thermo Fisher Scientific), which was used in order to explore MSC aggregation and spheroid formation. A total of $10 \mathrm{~mL}$ of suspension of each MSCs line at passage 4 with a density of $2 \times 10^{6}$ cells $/ \mathrm{mL}$ was seeded into the bacterial-grade dish. Additionally, a dish pre-treated with the HA product was used. Seeded MSCs did not exhibit plastic adherent properties due to the natural adherence between cells forming aggregates without shaking [28]. The duration of the experiments was 10 days, and the medium had been refreshed after 3 days. An inverted microscope was utilized for viewing and assessing the morphological changes (Nikon Eclipse E100 microscope with a DS-2Mv-L2 digital camera).

\subsection{Functionality Tests}

For each functionality test, the three MSC lines were grown in conventional culture medium as well as in HA-containing culture medium.

\subsubsection{Colony-Forming Unit-Fibroblast (CFU-F) Assay}

The CFU-F test was used in order to qualify isolated cells as MSCs. The CFU-F test was completed based on the approach described by Castro-Malaspina (1980) [29]. Essentially, the cells isolated from gingival and granulation tissues of systemic sclerosis patients as well as normal gingiva-derived cells were plated at 100 cells/Petri dish $\left(100 \mathrm{~cm}^{2}\right.$ dishes $)$ and incubated at $37^{\circ} \mathrm{C}$ in a humidified atmosphere of $5 \% \mathrm{CO}_{2}$ for 10 days, with the culture medium replaced at 3 days. Initially, HA was added into experimental culture media only for the first 3 days. The cultures were stained with $0.5 \%$ crystal violet (Sigma-Aldrich) in $100 \%$ methanol for $30 \mathrm{~min}$ and then observed under phase contrast inverted light microscope (Nikon TS100, Nikon Instruments, Melville, NY, USA). The colonies ( $>50$ cells) were counted. An estimation of CFU-F efficiency was carried out utilizing the following formula: CFU-F efficiency $=($ counted CFU-F/cells originally seeded $) \times 100$.

\subsubsection{Migration Potential}

For evaluating the migration potential of the three types of MSCs, a number of $2.5 \times 10^{2}$ cells were aggregated in hanging drop cultures in both experimental media. The spheroid aggregates obtained were harvested at $48 \mathrm{~h}$ and transferred into 6-well plates pre-treated with $0.1 \%$ gelatine (Sigma-Aldrich) to allow the aggregates to attach and the MSCs to migrate out of the aggregates. The migration area was obtained at $24 \mathrm{~h}$, based on aggregate size measurement and an estimation of the area covered by MSCs after migration. The following formula: migration area = MSC migration area—aggregate size was used. 


\subsection{Statistical Analysis}

Statistical analysis was performed using the MedCalc ${ }^{\circledR}$ Statistical Software version 20.008 (MedCalc Software Ltd., Ostend, Belgium; https: / / www.medcalc.org (accessed on 22 June 2021). Data were characterized by mean and standard deviation $( \pm \mathrm{SD})$ (normal distribution). Comparison between two groups (HA-treated vs. controls) was performed using the Student $t$-test. Comparison between three groups (hMSCs, SScgMSCs, SScgtMSCs) was performed using the one-way ANOVA. A $p$-value lower than 0.05 was considered statistically significant.

\section{Results}

\subsection{Characterization of MSCs}

\subsubsection{Surface Markers of MSCs}

Three types of oral tissular remnants were used to obtain single-cell suspensions for identifying the putative MSCs. Putative MSCs were cultured under normal culture conditions or in an HA-containing medium and characterized in several ways. MSCs firmly adhered to the plastic surface of the culture plates and presented a fibroblast-like morphology that remained unchanged during the passage process.

Flow cytometry was used to show the percentage of positive cells for the cells-surface markers. The immunophenotypic characterization of MSCs revealed that the cells were positively stained for the following surface markers: CD29, CD73, CD90, CD105, CD44, and CD79a (Table 1, Figures S1 and S2). In contrast, a negative expression of CD34, CD45, HL-DR, andCD14 was associated with these cells.

Table 1. Surface antigen make-up in experimental cell lines.

\begin{tabular}{|c|c|c|c|c|c|c|c|c|c|}
\hline $\begin{array}{c}\text { Antigen (\%) } \\
\text { Cell Line }\end{array}$ & CD73 & CD90 & CD105 & $\mathrm{CD} 44$ & CD79a & CD34 & $\mathrm{CD} 45$ & HLA-DR & CD14 \\
\hline hMSCs & 100 & 99.7 & 99.8 & 97.5 & 0.2 & 0 & 0.1 & 0.1 & 0.1 \\
\hline SScgMSCss & 95.7 & 90.9 & 89.2 & 97.3 & 0 & 0 & 0 & 0 & 0 \\
\hline SScgtMSCs & 86.4 & 95 & 85 & 85.2 & 1.3 & 0.3 & 0.5 & 2.1 & 0.2 \\
\hline
\end{tabular}

\subsubsection{Trilineage Differentiation and Embryonic Body Formation}

To examine the multilineage differentiation of the isolated MSCs, cells were cultured in differentiation-inducing media. The culture of putative MSCs in an osteogenic induction medium for 21 days generated a calcified extracellular matrix, which was positively colored by Alizarin Red (Figure 1A,E,I), highlighting the in vitro osteogenic capacity of all three lines of MSCs. When putative MSCs were cultured in an adipogenic medium for 30 days, the lipid vacuoles generated by the cells were colored by Oil Red O (Figure 1B,F,J). The culture of the cells in a chondrogenic medium for 30 days induced the formation of the extracellular matrix rich in proteoglycan, which was stained by Alcian Blue (Figure 1C,G,K).

The formation of unattached clusters or spheroids resembling embryonic bodies after 10 days of seeding of MSCs onto bacterial-grade dishes was highlighted (Figure 1D,H,L).

The putative MSCs have also been differentiated into adipogenic, osteogenic, and chondrogenic lineages when cultured in HA-containing differentiation media (Figure 2). 

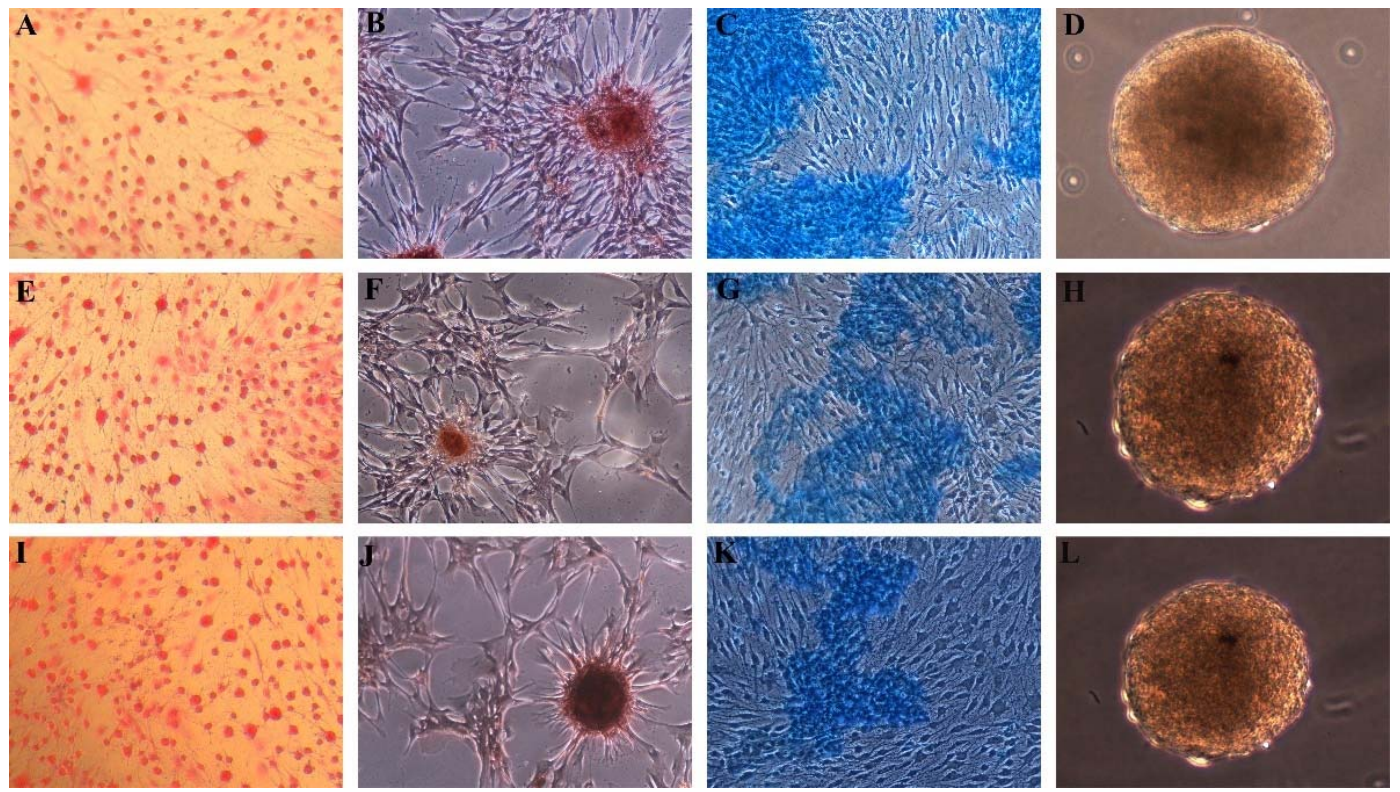

Figure 1. Differentiation of MSCs grown in normal medium. Positive Oil Red O staining of adipogenic induced cells from (A) hMSCs, (E) SScgMSCs, (I) SScgtMSCs; positive Alzarin red staining of osteoblasts derived from (B) hMSCs, (F) SScgMSCs, (J) SScgtMSCs; Alcian Blue staining of chondroblasts derived from (C) hMSCs, (G) SScgMSCs, (K) SScgtMSCs; embryonic bodies derived from (D) hMSCs, (H) SScgMSCs, (L) SScgtMSCs. MSCs = mesenchymal stromal cells, hMSCs = healthy MSCs, SScgMSCs = gingival MSCs, SScgtMSCs = granulation tissue MSCs, SSc = systemic sclerosis.
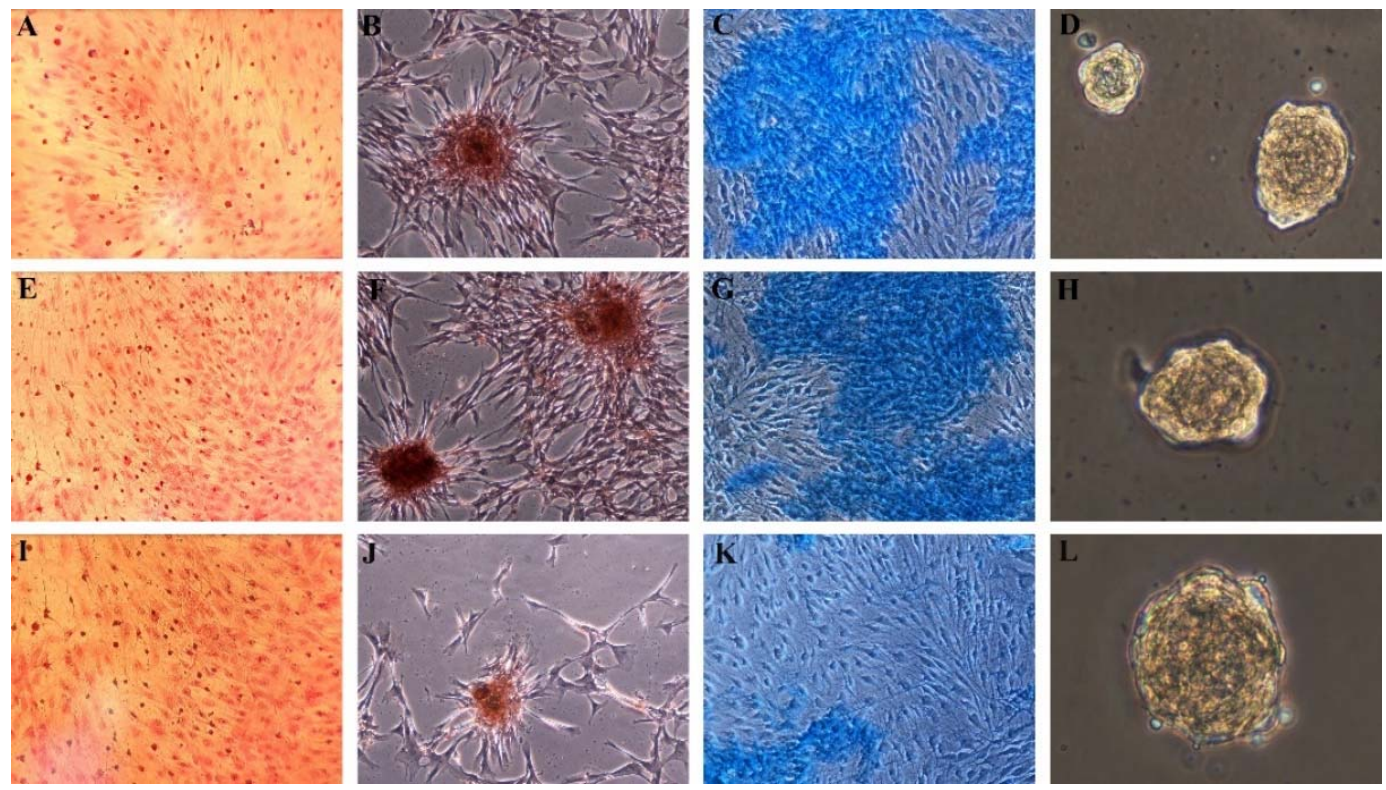

Figure 2. Differentiation of MSCs grown in HA-containing medium. Positive Oil Red O staining of adipogenic induced cells from (A) hMSCs, (E) SScgMSCs, (I) SScgtMSCs; positive Alzarin red staining of osteoblasts derived from (B) hMSCs, (F) SScgMSCs, (J) SScgtMSCs; Alcian Blue staining of chondroblasts derived from (C) hMSCs, (G) SScgMSCs, (K) SScgtMSCs; embryonic bodies derived from (D) hMSCs, (H) SScgMSCs, (L) SScgtMSCs. MSCs = mesenchymal stromal cells, hMSCs = healthy MSCs, SScgMSCs = gingival MSCs, SScgtMSCs = granulation tissue MSCs, SSc = systemic sclerosis.

\subsection{Functionality Tests}

3.2.1. Colony-Forming Unit-Fibroblast (CFU-F) Assay

All cell lines grew well in both culture conditions (normal and HA-containing medium), as demonstrated by their ability to form CFUs. On day 10, the intragroup comparisons 
showed no statistical differences in the frequency of colony-forming units for all cell lines grown in the normal medium (control) as compared to the HA-containing medium: hMSCs-77.67 ( \pm 4.1633$)$ (control), $74.67( \pm 5.8594)(\mathrm{HA})(p=0.51) ;$ SScgMSCs—78.67 $( \pm 2.517)$ (control), $83.67( \pm 3.786)$ (HA $(p=0.129)$; SScgtMSCs—61.33 ( \pm 4.5092$)$ (control), $65.33( \pm 4.7258)(\mathrm{HA})(p=0.349)$.

When comparing cell lines plated in the control medium, significant statistical differences $(p=0.002)$ between CFU values were calculated. SScgtMSCs formed less CFU than hMSCs $(p=0.05)$ and SScgMSCs $(p=0.004)$, respectively. hMSCs and SScgMSCs plated in the control medium showed similar CFU values $(p=0.946)$.

When cell lines were cultivated in HA-containing medium, the frequency of colonyforming cells of SScgtMSCs was significantly lower than for SScgMSCs $(p=0.009)$. No significant differences were recorded when hMSC CFU values were compared to SScgMSCs $(p=0.138)$ and SScgtMSCs $(p=0.124)$ values under similar plating conditions (Figure 3A).

A

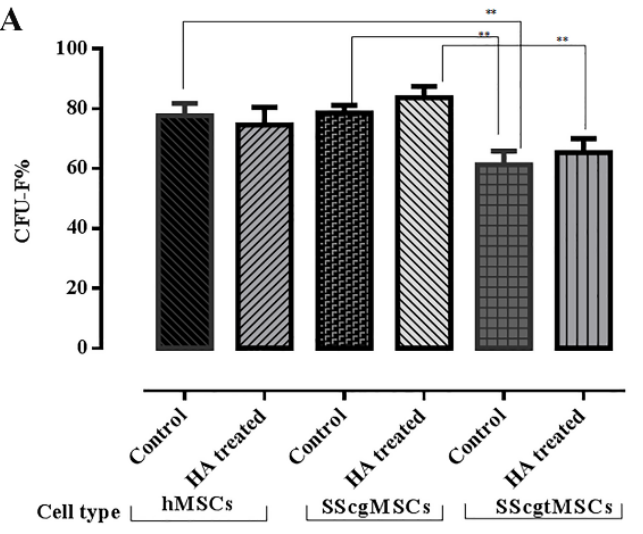

B

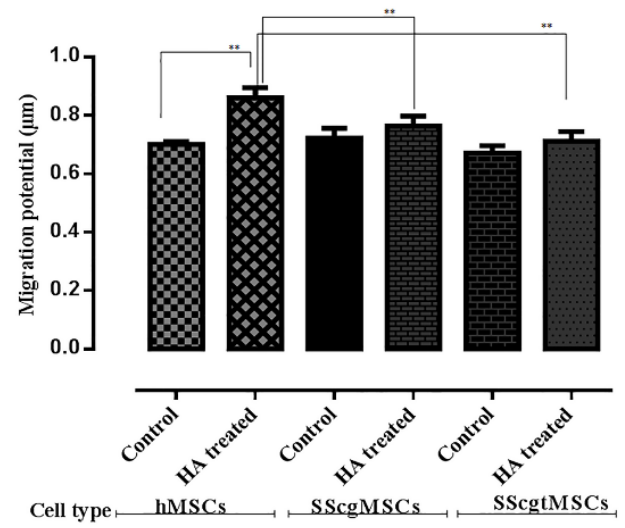

Figure 3. Grafical representation of functionality tests. (A). Colony-Forming Units (CFU) test; (B) migration potential test. MSCs = mesenchymal stromal cells, hMSCs = healthy MSCs, SScgMSCs = gingival MSCs, SScgtMSCs = granulation tissue MSCs, $\mathrm{SSc}=$ systemic sclerosis; ${ }^{* *} p \leq 0.05$.

\subsubsection{Migration Potential}

Migratory potential of isolated cells was determined in order to investigate the impact of general disease and of HA (Figure 3B). Following culture for $48 \mathrm{~h}$, the migratory potential values of hMSCs showed a statistically significant difference for cells grown in normal medium (control) as compared to HA-containing medium: $0.7016( \pm 0.0095)$ (control), $0.86( \pm 0.0356)(\mathrm{HA})(p=0.012)$. No significant differences were recorded for the other two cell lines cultivated in normal medium in comparison to HA-containing medium: SScgMSCs—0.723 ( \pm 0.034$)$ (control), $0.764( \pm 0.0342)(\mathrm{HA})(p=0.215) ;$ SScgtMSCs -0.6723 $( \pm 0.0241)$ (control), $0.7116( \pm 0.0335)(\mathrm{HA})(p=0.175)$.

No significant differences in migration potential $(p=0.115)$ were recorded when the three MSC types cultured in control medium were compared (hMSCs vs. SScgMSCs $p=0.572$; hMSCs vs. SScgtMSCs, $p=0.376$; SScgMSCs vs. SScgtMSCs, $p=0.101$ ), whereas significant differences in migration potential between the cell lines grown in HA-containing medium have been recorded $(p=0.05)$. HA significantly stimulated the migration of hMSCs in comparison to SScgMSCs $(p=0.033)$ and SScgtMSCs $(p=0.005)$, whereas no differences in migration potential values were observed when SScgMSCs and SScgtMSCs were compared $(p=0.231)$.

\section{Discussions}

SSc is a life-threatening disease with general critical implications and a wide range of oral manifestations [30]. It was reported that in SSc, resident MSCs might be dysfunctional and participate in disease progression, but this information is inconsistent [31,32]. Since the academic literature associated with this topic reveals limited information and knowledge on the oral MSCs from SSCs, the proposed framework underlines the novelty of our study. 
The present study isolated MSCs from gingiva and periapical granulation tissue from an SSc patient, characterized the isolated cells, and compared their properties to data concerning gingival MSCs isolated from a healthy patient in two different growing conditions. Isolation of MSCs from gingival and granulation tissues from SSc is not surprising as the oral cavity has proven to be an important source of progenitors [33-37]. The fulfillment of standard minimal criteria for defining multipotent MSCs [25] appears to confirm that isolated cells present the essential features of MSCs, such as plastic adhesion properties without phenotypic change, special surface antigen make-up, and differentiation potential. Both SSc-derived MSCs show a relatively reduced expression of surface antigens CD73, CD90, and CD105 in comparison to hMSCs, which is in agreement with the results reported by others [34,38]. The inflammatory conditions could inhibit the expression of CD105 [38]. CD105 is a glycoprotein involved in the modulation of TGF-beta (transforming growth factor-beta) receptor signaling, which regulates cell morphology, migration, and proliferation, thus impacting MSCs and tumor growth and metastasis [39]. CD90 influences cell-cell and cell-matrix interactions, cell adhesion and migration, cytoskeleton organization, and tissue regeneration [40]. Reduced expression of CD90 was not associated with modifications of the morphology, proliferation rate, or immunosuppressive potential of MSCs, but augmented the differentiation potential of MSCs toward osteogenic and adipogenic lineages [41].

More recent information reported no significant differences in marker profiles of MSCs from SSC compared with healthy cells [42].

The results of this experiment demonstrate the potential of isolated MSCs to generate osteoblasts, adipocytes, and chondroblasts. However, prior research has found an alteration in the differentiation potential of MSCs into osteoblasts and adipocytes [11]. This biological multilineage differentiation property is a unique identification feature of MSCs [25]. Furthermore, the spontaneous generation of embryoid bodies in certain conditions also indicated the differentiation capabilities of MSCs. As shown by Kurosawa [43] and Roman et al. [33], these embryoid bodies form three-dimensional multicellular aggregates of differentiated and undifferentiated cells. Additionally, it has also been revealed that embryoid bodies could comprise precursor cells to mesenchymal as well as neural stem cell lineages [11,44-47].

Overall, the study's findings suggest a reduced functionality of MSCs derived from SSc as compared to MSCs from healthy tissues, although recent data showed normal CFU-F capability of MSCs isolated from SSc and healthy patients [42]. CFU-F formation capacity was demonstrated for putative MSCs isolated from SSc. Additionally, CFU-F frequency was significantly lower for SScgtMSCs than in the case of hMSCs $(p=0.05)$ and SScgMSCs $(p=0.004)$ in normal plating conditions. CFU-F frequency of SScgtMSCs also remained lower than that observed for SScgMSCs $(p=0.09)$ in the HA-containing medium. When plated in HA-containing conditions, both SSc-derived cell lines (SScgMSCs and SScgtMSCs) migrated significantly less ( $p=0.033$ and $p=0.005$, respectively) than hMSCs. These results are in agreement with data provided by other researchers [11,44], while some studies reported no phenotype or functionality alterations in SSc-derived MSCs, compared to MSCs from healthy subjects [14,48].

According to our results, SScgtMSCs appeared to be more dysfunctional than SScgMSCs, as they displayed impaired CFU formation in both normal and HA-containing conditions. This confirms previous data $[34,37,49]$ suggesting that MSCs stem cell properties could be impacted by inflammation [50] rather than the SSc per se. Other studies reported that MSCs derived from inflamed tissues showed resistance to inflammatory stimuli, as no impairments had been highlighted [26,36,51]. On the other hand, the functional disparities observed in the case of SScgMSCs should be considered as a direct effect of the general disease. The present study recorded a more dysfunctional behavior of SSc-derived MSCs as compared to hMSCs. Thus, the data from the present experiment suggest rejection of the null hypothesis. However, more oral samples derived from SSc patients should be analyzed in order to better "portray" the behavior of oral MSCs. 
However, there are still some underlying uncertainties with regard to the disparities of MSCs harvested from other SSc-associated regions. One explanation may lie in the fact that resident MSCs might be involved in SSc pathogenesis through different pathways such as an increase in TGF $\beta$-R2 (transforming growth factor, beta receptor II) at the surface of SSc-MSCs in comparison with the same type of healthy cells and an increased sensibility to TGF $\beta$, which up-regulates this pathway and increases the synthesis of collagen 1 [52], the modification of the angiogenic capacity of MSCs due to overexpression of pro-angiogenic factors (i.e., VEGF-A vascular endothelial growth factor A) [53] and higher telomerase activity, inducing early senescence [11]. On the other hand, some data sustained that adipose tissue MSCs from SSc do not display the alterations observed in bone-marrow-derived MSCs [14]. In SSc, infusions with autologous adipose tissue MSCs would provide local and time-limited immunosuppression in comparison with conventional immunosuppressants [54]. However, recent data reported the potential contribution of white adipose tissue and the adipocytic lineages to the pathologic phenomena in SSc $[55,56]$ and the loss of subcutaneous adipose tissue in SSc [57]. The mentioned shortcomings make these approaches more questionable than the allogeneic techniques that are presently recommended as the gold standard to treat SSc lesions [58].

Further studies should elucidate whether the impairments of progenitors are due to the pathological milieu or to the intrinsic modification of SSc pathogenetic pathways, and new research should assess diverse sources of MSCs from SSc patients and identify the lineages displaying the most appropriate properties [58] as potential treatment instruments of this general disease [54]. This sustains the novelty of our study in trying to identify new sources of MSCs with possibly better properties.

MSCs of different tissular origins have relatively uniform surface antigenic markers but display various genetic fingerprints responsible for the secretion of specific biological active molecules that have particular therapeutic consequences [59]. From this perspective emerges another limitation of our study related to the lack of investigation of the genetic profile of experimental cell lines and quantification of the ability to differentiate, especially in adipocytic lines-important players sustaining the attenuation of some SSc subcutaneous lesions [60]. Efforts will be completed to develop further evaluations on these issues.

Another novelty of our experiment is to show the effect of HA on oral MSCs from SSc, as to our knowledge, extremely limited information has been provided on this topic. Data from our study allowed the identification of some stimulating effects of HA on MSC functions. Adding HA in the culture medium appeared to significantly stimulate the migration potential of hMSCs. Moreover, HA seemed to positively influence SScgMSCs compared to SScgtMSCs. Additionally, our review of the literature reveals that infusions with HA and adipose-derived MSCs in the treatment of affected skin areas of SSc patients offer definite clinical benefits [14]. The ready-applicable MSC-based clinical approaches addressing regeneration of oral structures are an extremely appealing tool of regenerative medicine [61]; however, they have not, to date, been made available [10]. Periodontal regeneration of affected tissues is a relatively unpredictable phenomenon [62], especially in the case of SSc associated with an impaired local environment. A positive point that needs to be taken into account is that HA molecules are already commercially available and, thus, could be used in periodontal interventions in SSc patients, providing wound healing, bacteriostatic, and anti-inflammatory effects $[17,19,23]$, and contributing to ameliorating the behavior of local MSCs. Reduction of inflammation could be the consequence of the antimicrobial effect of HA as well as the direct interference/effect of inflammation pathways. As for wound healing, it has been demonstrated that initially, low-molecular-weight hyaluronan binds fibrinogen, promoting clot formation, and provides anti-angiogenic and immunosuppressive effects [63]. Moreover, the low-molecular-weight hyaluronan protects against apoptosis based on a pathway associated with nuclear factor kappa-B (NF-кB). In an inflammatory environment, the low-molecular-weight hyaluronan is broken into low-molecular-weight molecules [64], which stimulate angiogenesis [65] as well as phagocytosis and chemotaxis of neutrophils [66], local secretion of pro-inflammatory cytokines, 
and matrix metalloproteinases [67]. However, the exact mechanisms of hyaluronan are currently unknown [16]. Positive influences of topical applications of HA in gingivitis [24] and nonsurgical $[16,68]$ or surgical treatment of periodontitis [69] have been reported in healthy patients.

The isolation and characterization of oral MSCs from SSc along with an analysis of their behavior in relation to normal MSCs and HA constitute the novelty of this study; however, given the limited number of samples, further verification and studies are needed in order to draw firm conclusions on this topic. Oral tissues are an accessible and abundant source of MSCs and a promising alternative for regenerative medicine. More research on oral MSCs from SSc is needed to provide useful information for clinical translation in the complex treatment of SSc. HA could be used as an adjunctive of periodontal treatments in SSc patients for stimulating progenitor pools and increasing repair and regeneration.

\section{Conclusions}

The isolated cells from the gingival tissue and apical lesion from SSc display MSC characteristics. Some dysfunctions of MSCs from SSc regarding CFU-F formation and migration potential in comparison with hMSCs were observed. The functional impairments persist when SSc-derived cells are grown in association with HA, especially for SScgtMSCs. HA appears to positively influence the functionality of hMSCs.

Supplementary Materials: The following are available online at https: / www.mdpi.com/article / 10.3390/app11178101/s1: Figure S1. Flow cytometric analysis of MSCs: positive surface markers. Stoma 30 = hMSCs; stoma 31= SScgMSCs; stoma 32 = SScgtMSCs. MSCs = mesenchymal stromal cells, $\mathrm{h}$ = healthy gingiva, $\mathrm{g}=$ gingiva from systemic sclerosis, $\mathrm{gt}$ = granulation tissue from systemic sclerosis. Figure S2. Flow cytometric analysis of MSCs: negative surface markers. Stoma $30=\mathrm{hMSC}$; stoma 31 = SScgMSCs; stoma 32 = SScgtMSCs. MSCs = mesenchymal stromal cells, $\mathrm{h}=$ healthy gingiva, $\mathrm{g}=$ gingiva from systemic sclerosis, $\mathrm{gt}$ = granulation tissue from systemic sclerosis.

Author Contributions: Conceptualization, A.R., A.S. (Andrada Soancă) and A.P.-W.; Data Curation, A.S. (Alina Stanomir), I.C.M. and A.E.B.; Formal analysis, I.C.M. and A.E.B.; Funding Acquisition, A.S. (Alina Stanomir); Investigation, A.S. (Alina Stanomir), C.M.M. and E.P.; Methodology, C.M.M., S.R., A.R., A.S. (Andrada Soancă) and A.P.-W.; Project Administration, S.R. and A.S. (Andrada Soancă); Resources, A.S. (Alina Stanomir) and C.P.; Validation, A.S. (Alina Stanomir), S.R. and Stefan-Ioan Stratul; Writing-Original Draft, Alina Stanomir, Cristina Pamfil, Alexandra Roman, S.I.S. and E.P.; Writing-Review and Editing, C.M.M., S.R., A.E.B. and S.I.S. All authors have read and agreed to the published version of the manuscript.

Funding: This research was funded by the Iuliu Hațieganu University of Medicine and Pharmacy Cluj-Napoca, PCD grants 2461/69/17.01.2020 and 1033/61/13.01.2021.

Institutional Review Board Statement: The investigations carried out in the present study met the regulations contained in the Declaration of Helsinki and were authorized by the Ethical Board of the Iuliu Hatieganu University of Medicine and Pharmacy Cluj-Napoca (No. 96/9.03.2020).

Informed Consent Statement: Informed consent to use the oral tissue remnants for research purposes was obtained from the subjects involved in the study.

Data Availability Statement: The datasets generated during the current study are available from the corresponding author on reasonable request.

Acknowledgments: We are grateful to Stefan Vesa for performing the statistical analysis and Adriana Lazăr for the English proofing.

Conflicts of Interest: The authors declare no competing interests. 


$\begin{array}{ll}\text { Abbreviations } & \\ \text { CFU-F } & \text { Colony-Forming Unit-Fibroblast } \\ \text { SSc } & \text { Systemic sclerosis } \\ \text { SScgMSCs } & \text { Gingival MSCs from a SSc patient } \\ \text { SScgtMSCs } & \text { Granulation tissue MSCs from an SSc patient } \\ \text { hMSCs } & \text { MSCs from a healthy individual } \\ \text { HA } & \text { Hyaluronic acid } \\ \text { MSCs } & \text { Mesenchymal stromal cell }\end{array}$

\section{References}

1. Jimenez, S.A.; Derk, C.T. Following the Molecular Pathways toward an Understanding of the Pathogenesis of Systemic Sclerosis. Ann. Intern. Med. 2004, 140, 37-50. [CrossRef] [PubMed]

2. Servettaz, A.; Agard, C.; Tamby, M.C.; Guilpain, P.; Guillevin, L.; Mouthon, L. Systemic sclerosis: Pathophysiology of a multifaceted disease. Presse Med. 2006, 35, 1903-1915. [CrossRef]

3. Mouthon, L.; Rannou, F.; Bérezné, A.; Pagnoux, C.; Arène, J.-P.; Foïs, E.; Cabane, J.; Guillevin, L.; Revel, M.; Fermanian, J.; et al. Development and Validation of a Scale for Mouth Handicap in Systemic Sclerosis: The Mouth Handicap in Systemic Sclerosis Scale. Ann. Rheum. Dis. 2007, 66, 1651-1655. [CrossRef]

4. $\quad$ Elimelech, R.; Mayer, Y.; Braun-Moscovici, Y.; Machtei, E.E.; Balbir-Gurman, A. Periodontal Conditions and Tumor Necrosis Factor-Alpha Level in Gingival Crevicular Fluid of Scleroderma Patients. Isr. Med. Assoc. J. IMAJ 2015, 17, 549-553.

5. Leung, W.K.; Chu, C.H.; Mok, M.Y.; Yeung, K.S.; Ng, S.K. Periodontal Status of Adults with Systemic Sclerosis: Case-Control Study. J. Periodontol. 2011, 82, 1140-1145. [CrossRef]

6. Pischon, N.; Hoedke, D.; Kurth, S.; Lee, P.; Dommisch, H.; Steinbrecher, A.; Pischon, T.; Burmester, G.R.; Buttgereit, F.; Detert, J.; et al. Increased Periodontal Attachment Loss in Patients with Systemic Sclerosis. J. Periodontol. 2016, 87, 763-771. [CrossRef] [PubMed]

7. Veale, B.J.; Jablonski, R.Y.; Frech, T.M.; Pauling, J. Orofacial manifestations of systemic sclerosis. Br. Dent. J. 2016, 221, 305-310. [CrossRef] [PubMed]

8. Jung, S.; Martin, T.; Schmittbuhl, M.; Huck, O. The spectrum of orofacial manifestations in systemic sclerosis: A challenging management. Oral Dis. 2017, 23, 424-439. [CrossRef] [PubMed]

9. Scardina, G.; Pizzigatti, M.; Messina, P. Periodontal Microcirculatory Abnormalities in Patients with Systemic Sclerosis. J. Periodontol. 2005, 76, 1991-1995. [CrossRef] [PubMed]

10. Duscher, D.; Barrera, J.F.; Wong, V.W.; Maan, Z.; Whittam, A.J.; Januszyk, M.; Gurtner, G.C. Stem Cells in Wound Healing: The Future of Regenerative Medicine? A Mini-Review. Gerontology 2015, 62, 216-225. [CrossRef]

11. Del Papa, N.; Quirici, N.; Soligo, D.; Scavullo, C.; Cortiana, M.; Borsotti, C.; Maglione, W.; Comina, D.P.; Vitali, C.; Fraticelli, P.; et al. Bone marrow endothelial progenitors are defective in systemic sclerosis. Arthritis Rheum. 2006, 54, 2605-2615. [CrossRef]

12. Di Benedetto, P.; Panzera, N.; Cipriani, P.; Mastroiaco, V.; Tessitore, A.; Liakouli, V.; Ruscitti, P.; Berardicurti, O.; Carubbi, F.; Guggino, G.; et al. Mesenchymal stem cells of Systemic Sclerosis patients, derived from different sources, show a profibrotic microRNA profiling. Sci. Rep. 2019, 9, 7144. [CrossRef]

13. Larghero, J.; Farge, D.; Braccini, A.; Lecourt, S.; Scherberich, A.; Foïs, E.; Verrecchia, F.; Daikeler, T.; Gluckman, E.; Tyndall, A.; et al. Phenotypical and functional characteristics of in vitro expanded bone marrow mesenchymal stem cells from patients with systemic sclerosis. Ann. Rheum. Dis. 2007, 67, 443-449. [CrossRef]

14. Scuderi, N.; Ceccarelli, S.; Onesti, M.G.; Fioramonti, P.; Guidi, C.; Romano, F.; Frati, L.; Angeloni, A.; Marchese, C. Human Adipose-Derived Stromal Cells for Cell-Based Therapies in the Treatment of Systemic Sclerosis. Cell Transplant. 2013, 22, 779-795. [CrossRef] [PubMed]

15. Fraser, J.R.E.; Laurent, T.C.; Laurent, U.B.G. Hyaluronan: Its nature, distribution, functions and turnover. J. Intern. Med. 1997, 242, 27-33. [CrossRef] [PubMed]

16. Bertl, K.; Bruckmann, C.; Isberg, P.-E.; Klinge, B.; Gotfredsen, K.; Stavropoulos, A. Hyaluronan in non-surgical and surgical periodontal therapy: A systematic review. J. Clin. Periodontol. 2015, 42, 236-246. [CrossRef]

17. Carlson, G.A.; Dragoo, J.L.; Samimi, B.; Bruckner, D.A.; Bernard, G.W.; Hedrick, M.; Benhaim, P. Bacteriostatic properties of biomatrices against common orthopaedic pathogens. Biochem. Biophys. Res. Commun. 2004, 321, 472-478. [CrossRef]

18. Kang, J.-H.; Kim, Y.-Y.; Chang, J.-Y.; Kho, H.-S. Influences of hyaluronic acid on the anticandidal activities of lysozyme and the peroxidase system. Oral Dis. 2011, 17, 577-583. [CrossRef] [PubMed]

19. Laurent, T.C.; Laurent, U.B.; Fraser, J.R. Functions of hyaluronan. Ann. Rheum. Dis. 1995, 54, 429-432. [CrossRef]

20. de Brito Bezerra, B.; Mendes Brazão, M.A.; de Campos, M.L.G.; Casati, M.Z.; Sallum, E.A.; Sallum, A.W. Association of Hyaluronic Acid with a Collagen Scaffold May Improve Bone Healing in Critical-Size Bone Defects. Clin. Oral Implant. Res. 2011, 23, 938-942. [CrossRef]

21. Mendes, R.M.; Silva, G.A.; Caliari, M.V.; Silva, E.E.; Ladeira, L.O.; Ferreira, A.J. Effects of single wall carbon nanotubes and its functionalization with sodium hyaluronate on bone repair. Life Sci. 2010, 87, 215-222. [CrossRef] 
22. Deed, R.; Rooney, P.; Kumar, P.; Norton, J.D.; Smith, J.; Freemont, A.J.; Kumar, S. Early-response gene signalling is induced by angiogenic oligosaccharides of hyaluronan in endothelial cells. Inhibition by non-angiogenic, high-molecular-weight hyaluronan. Int. J. Cancer 1997, 71, 251-256. [CrossRef]

23. Chen, W.Y.J.; Abatangelo, G. Functions of hyaluronan in wound repair. Wound Repair Regen. 1999, 7, 79-89. [CrossRef]

24. Jentsch, H.; Pomowski, R.; Kundt, G.; Göcke, R. Treatment of gingivitis with hyaluronan. J. Clin. Periodontol. 2003, 30, 159-164. [CrossRef] [PubMed]

25. Dominici, M.; Le Blanc, K.; Mueller, I.; Slaper-Cortenbach, I.; Marini, F.; Krause, D.; Deans, R.; Keating, A.; Prockop, D.; Horwitz, E. Minimal criteria for defining multipotent mesenchymal stromal cells. The International Society for Cellular Therapy position statement. Cytotherapy 2006, 8, 315-317. [CrossRef] [PubMed]

26. Soancă, A.; Lupse, M.; Moldovan, M.; Pall, E.; Cenariu, M.C.; Roman, A.; Tudoran, O.; Surlin, P.; Șorițău, O. Applications of inflammation-derived gingival stem cells for testing the biocompatibility of dental restorative biomaterials. Ann. Anat.-Anat. Anz. 2018, 218, 28-39. [CrossRef]

27. Pall, E.; Cenariu, M.; Kasaj, A.; Florea, A.; Soancă, A.; Roman, A.; Georgiu, C. New insights into the cellular makeup and progenitor potential of palatal connective tissues. Microsc. Res. Tech. 2017, 80, 1270-1282. [CrossRef] [PubMed]

28. Doetschman, T.C.; Eistetter, H.; Katz, M.; Schmidt, W.; Kemler, R. The in vitro development of blastocyst-derived embryonic stem cell lines: Formation of visceral yolk sac, blood islands and myocardium. J. Embryol. Exp. Morphol. 1985, 87, $27-45$.

29. Castro-Malaspina, H.; Gay, R.E.; Resnick, G.; Kapoor, N.; Meyers, P.; Chiarieri, D.; McKenzie, S.; Broxmeyer, H.E.; Moore, M.A. Characterization of Human Bone Marrow Fibroblast Colony-Forming Cells (CFU-F) and Their Progeny. Blood 1980, 56, $289-301$. [CrossRef]

30. Crincoli, V.; Fatone, L.; Fanelli, M.; Rotolo, R.P.; Chialà, A.; Favia, G.; Lapadula, G. Orofacial Manifestations and Temporomandibular Disorders of Systemic Scleroderma: An Observational Study. Int. J. Mol. Sci. 2016, 17, 1189. [CrossRef]

31. Cipriani, P.; Di Benedetto, P.; Liakouli, V.; Del Papa, B.; DI Padova, M.; Di Ianni, M.; Marrelli, A.; Alesse, E.; Giacomelli, R. Mesenchymal stem cells (MSCs) from scleroderma patients (SSc) preserve their immunomodulatory properties although senescent and normally induce T regulatory cells (Tregs) with a functional phenotype: Implications for cellular-based therapy. Clin. Exp. Immunol. 2013, 173, 195-206. [CrossRef]

32. Cipriani, P.; Di Benedetto, P.; Ruscitti, P.; Campese, A.F.; Liakouli, V.; Carubbi, F.; Pantano, I.; Berardicurt, O.; Screpanti, I.; Giacomelli, R. Impaired Endothelium-Mesenchymal Stem Cells Cross-talk in Systemic Sclerosis: A Link Between Vascular and Fibrotic Features. Arthritis Res. Ther. 2014, 16, 442. [CrossRef] [PubMed]

33. Roman, A.; Şoancă, A.; Florea, A.; Páll, E. In Vitro Characterization of Multipotent Mesenchymal Stromal Cells Isolated from Palatal Subepithelial Tissue Grafts. Microsc. Microanal. 2013, 19, 370-380. [CrossRef]

34. Páll, E.; Florea, A.; Soriţău, O.; Cenariu, M.; Petruţiu, A.S.; Roman, A. Comparative Assessment of Oral Mesenchymal Stem Cells Isolated from Healthy and Diseased Tissues. Microsc. Microanal. 2015, 21, 1249-1263. [CrossRef] [PubMed]

35. Chen, S.C.; Marino, V.; Gronthos, S.; Bartold, P.M. Location of putative stem cells in human periodontal ligament. J. Periodontal Res. 2006, 41, 547-553. [CrossRef]

36. Park, J.-C.; Kim, J.-M.; Jung, I.-H.; Kim, J.C.; Choi, S.-H.; Cho, K.S.; Kim, C.-S. Isolation and characterization of human periodontal ligament (PDL) stem cells (PDLSCs) from the inflamed PDL tissue: In vitro and in vivo evaluations. J. Clin. Periodontol. 2011, 38, 721-731. [CrossRef] [PubMed]

37. Yazid, F.B.; Gnanasegaran, N.; Kunasekaran, W.; Govindasamy, V.; Musa, S. Comparison of immunodulatory properties of dental pulp stem cells derived from healthy and inflamed teeth. Clin. Oral Investig. 2014, 18, 2103-2112. [CrossRef] [PubMed]

38. Tang, H.-N.; Xia, Y.; Yu, Y.; Wu, R.-X.; Gao, L.-N.; Chen, F.-M. Stem cells derived from "inflamed" and healthy periodontal ligament tissues and their sheet functionalities: A patient-matched comparison. J. Clin. Periodontol. 2015, 43, 72-84. [CrossRef]

39. Morine, K.J.; Paruchuri, V.; Qiao, X.; Aronovitz, M.; Huggins, G.S.; Denofrio, D.; Kiernan, M.S.; Karas, R.H.; Kapur, N.K. Endoglin selectively modulates transient receptor potential channel expression in left and right heart failure. Cardiovasc. Pathol. 2016, 25, 478-482. [CrossRef]

40. Rege, T.A.; Hagood, J.S. Thy-1 as a regulator of cell-cell and cell-matrix interactions in axon regeneration, apoptosis, adhesion, migration, cancer, and fibrosis. FASEB J. 2006, 20, 1045-1054. [CrossRef]

41. de Carvalho, L.A.C.; Dos Santos, S.L.T.; Sacramento, L.V.; de Almeida Júnior, V.R.; de Aquino Xavier, F.C.; Dos Santos, J.N.; Leitão, Á.C.G.H. Mesenchymal stem cell markers in periodontal tissues and periapical lesions. Acta Histochem. 2020, $122,151636$. [CrossRef]

42. Rozier, P.; Maria, A.; Goulabchand, R.; Jorgensen, C.; Guilpain, P.; Noël, D. Mesenchymal Stem Cells in Systemic Sclerosis: Allogenic or Autologous Approaches for Therapeutic Use? Front. Immunol. 2018, 9, 2938. [CrossRef] [PubMed]

43. Kurosawa, H. Methods for inducing embryoid body formation: In vitro differentiation system of embryonic stem cells. J. Biosci. Bioeng. 2007, 103, 389-398. [CrossRef]

44. Cipriani, P.; Guiducci, S.; Miniati, I.; Cinelli, M.; Urbani, S.; Marrelli, A.; Dolo, V.; Pavan, A.; Saccardi, R.; Tyndall, A.; et al. Impairment of endothelial cell differentiation from bone marrow-derived mesenchymal stem cells: New insight into the pathogenesis of systemic sclerosis. Arthritis Rheum. 2007, 56, 1994-2004. [CrossRef] [PubMed]

45. Clarke, D.L.; Johansson, C.B.; Wilbertz, J.; Veress, B.; Nilsson, E.; Karlström, H.; Lendahl, U.; Frisén, J. Generalized Potential of Adult Neural Stem Cells. Science 2000, 288, 1660-1663. [CrossRef] [PubMed] 
46. Reynolds, B.; Weiss, S. Generation of neurons and astrocytes from isolated cells of the adult mammalian central nervous system. Science 1992, 255, 1707-1710. [CrossRef]

47. Rietze, R.L.; Valcanis, H.; Brooker, G.F.; Thomas, T.; Voss, A.K.; Bartlett, P.F. Purification of a pluripotent neural stem cell from the adult mouse brain. Nature 2001, 412, 736-739. [CrossRef]

48. Bocelli-Tyndall, C.; Bracci, L.; Spagnoli, G.; Braccini, A.; Bouchenaki, M.; Ceredig, R.; Pistoia, V.; Martin, I.; Tyndall, A. Bone marrow mesenchymal stromal cells (BM-MSCs) from healthy donors and auto-immune disease patients reduce the proliferation of autologous- and allogeneic-stimulated lymphocytes in vitro. Rheumatology 2006, 46, 403-408. [CrossRef]

49. Alongi, D.J.; Yamaza, T.; Song, Y.; Fouad, A.F.; Romberg, E.E.; Shi, S.; Tuan, R.S.; Huang, G.T.-J. Stem/progenitor cells from inflamed human dental pulp retain tissue regeneration potential. Regen. Med. 2010, 5, 617-631. [CrossRef]

50. Liao, J.; Al Shahrani, M.; Al-Habib, M.; Tanaka, T.; Huang, G.T.-J. Cells Isolated from Inflamed Periapical Tissue Express Mesenchymal Stem Cell Markers and Are Highly Osteogenic. J. Endod. 2011, 37, 1217-1224. [CrossRef]

51. Yu, B.; Zhang, X.; Li, X. Exosomes Derived from Mesenchymal Stem Cells. Int. J. Mol. Sci. 2014, 15, 4142-4157. [CrossRef]

52. Vanneaux, V.; Farge-Bancel, D.; Lecourt, S.; Baraut, J.; Cras, A.; Jean-Louis, F.; Brun, C.; Verrecchia, F.; Larghero, J.; Michel, L. Expression of transforming growth factor $\beta$ receptor II in mesenchymal stem cells from systemic sclerosis patients. BMJ Open 2013, 3, e001890. [CrossRef] [PubMed]

53. Guiducci, S.; Manetti, M.; Romano, E.; Mazzanti, B.; Ceccarelli, C.; Pozzo, S.D.; Milia, A.F.; Bellando-Randone, S.; Fiori, G.; Conforti, M.L.; et al. Bone marrow-derived mesenchymal stem cells from early diffuse systemic sclerosis exhibit a paracrine machinery and stimulate angiogenesis in vitro. Ann. Rheum. Dis. 2011, 70, 2011-2021. [CrossRef] [PubMed]

54. Maria, A.T.J.; Maumus, M.; Le Quellec, A.; Jorgensen, C.; Noël, D.; Guilpain, P. Adipose-Derived Mesenchymal Stem Cells in Autoimmune Disorders: State of the Art and Perspectives for Systemic Sclerosis. Clin. Rev. Allergy Immunol. 2016, 52, 234-259. [CrossRef]

55. Rosa, I.; Romano, E.; Fioretto, B.S.; Matucci-Cerinic, M.; Manetti, M. Adipose-derived stem cells: Pathophysiologic implications vs therapeutic potential in systemic sclerosis. World J. Stem Cells 2021, 13, 30-48. [CrossRef] [PubMed]

56. Manetti, M.; Romano, E.; Rosa, I.; Fioretto, B.S.; Praino, E.; Guiducci, S.; Iannone, F.; Ibba-Manneschi, L.; Matucci-Cerinic, M. Systemic Sclerosis Serum Steers the Differentiation of Adipose-Derived Stem Cells Toward Profibrotic Myofibroblasts: Pathophysiologic Implications. J. Clin. Med. 2019, 8, 1256. [CrossRef] [PubMed]

57. Marangoni, R.G.; Varga, J.; Tourtellotte, W.G. Animal models of scleroderma: Recent progress. Curr. Opin. Rheumatol. 2016, 28, 561-570. [CrossRef]

58. Abedi, M.; Alavi-Moghadam, S.; Payab, M.; Goodarzi, P.; Mohamadi-Jahani, F.; Sayahpour, F.A.; Larijani, B.; Arjmand, B Mesenchymal stem cell as a novel approach to systemic sclerosis; current status and future perspectives. Cell Regen. $2020,9,20$.

59. Pittenger, M.F.; Discher, D.E.; Péault, B.M.; Phinney, D.G.; Hare, J.M.; Caplan, A.I. Mesenchymal stem cell perspective: Cell biology to clinical progress. npj Regen. Med. 2019, 4, 1-15. [CrossRef]

60. Lee, R.; Reese, C.; Carmen-Lopez, G.; Perry, B.; Bonner, M.; Zemskova, M.; Wilson, C.L.; Helke, K.L.; Silver, R.M.; Hoffman, S.; et al. Deficient Adipogenesis of Scleroderma Patient and Healthy African American Monocytes. Front. Pharmacol. 2017, 8, 174. [CrossRef]

61. Lopes, B.; Sousa, P.; Alvites, R.; Branquinho, M.; Sousa, A.; Mendonça, C.; Atayde, L.; Maurício, A. The Application of Mesenchymal Stem Cells on Wound Repair and Regeneration. Appl. Sci. 2021, 11, 3000. [CrossRef]

62. Kao, R.T.; Nares, S.; Reynolds, M.A. Periodontal Regeneration-Intrabony Defects: A Systematic Review From the AAP Regeneration Workshop. J. Periodontol. 2015, 86, S77-S104. [CrossRef]

63. Asparuhova, M.B.; Chappuis, V.; Stähli, A.; Buser, D.; Sculean, A. Role of hyaluronan in regulating self-renewal and osteogenic differentiation of mesenchymal stromal cells and pre-osteoblasts. Clin. Oral Investig. 2020, 24, 3923-3937. [CrossRef] [PubMed]

64. Yamalik, N.; Kilinc, K.; Caglayan, F.; Eratalay, K.; Caglayan, G. Molecular size distribution analysis of human gingival proteoglycans and glycosaminoglycans in specific periodontal diseases. J. Clin. Periodontol. 1998, 25, 145-152. [CrossRef]

65. Aya, K.L.; Stern, R. Hyaluronan in wound healing: Rediscovering a major player. Wound Repair Regen. 2014, $22,579-593$. [CrossRef] [PubMed]

66. Håkansson, L.; Hällgren, R.; Venge, P. Regulation of granulocyte function by hyaluronic acid. In vitro and in vivo effects on phagocytosis, locomotion, and metabolism. J. Clin. Investig. 1980, 66, 298-305. [CrossRef]

67. Powell, J.D.; Horton, M.R. Threat Matrix: Low-Molecular-Weight Hyaluronan (HA) as a Danger Signal. Immunol. Res. 2005, 31, 207-218. [CrossRef]

68. Johannsen, A.; Tellefsen, M.; Wikesjö, U.; Johannsen, G. Local Delivery of Hyaluronan as an Adjunct to Scaling and Root Planing in the Treatment of Chronic Periodontitis. J. Periodontol. 2009, 80, 1493-1497. [CrossRef]

69. El-Sayed, K.M.F.; Dahaba, M.A.; Aboul-Ela, S.; Darhous, M.S. Local application of hyaluronan gel in conjunction with periodontal surgery: A randomized controlled trial. Clin. Oral Investig. 2011, 16, 1229-1236. [CrossRef] [PubMed] 